\title{
Prevalence of and risk factors for Enterobius vermicularis infestation in preschool children, West Bank, Palestine, 2015
}

Rasha Khayyat, ${ }^{1}$ Souad Belkebir, ${ }^{1}$ Sameh Abuseir, ${ }^{2}$ Majd Barahmeh, ${ }^{1}$ Lujain Alsadder ${ }^{1}$ and Walid Basha1

${ }^{1}$ Faculty of Medicine and Health Sciences, An-Najah National University, Nablus, West Bank, Palestine. ${ }^{2}$ Department of Veterinary Medicine, Faculty of Agriculture and Veterinary Medicine, An-Najah National University, Nablus, West Bank, Palestine (Correspondence to: Walid Basha: wbasha@najah. edu).

\begin{abstract}
Background: Enterobius vermicularis (pinworm) infestation is a common condition that primarily affects children.

Aims: The aim of this study was to assess the prevalence of and the risk factors for E. vermicularis infestation in preschool children in north West Bank.

Methods: A cross-sectional study that included the six main governorates in north West Bank was carried out on a sample of 384 preschool children from 86 day-care centres. The perianal cellophane tape method was used to detect E. vermicularis infestation. Parents/guardians of participating children completed a questionnaire to collect information about: demographic characteristics; hygiene behaviour; socioeconomic status; history of previous infestation; and presence of symptoms. Risk factors for infestation were assessed using logistic regression analysis.

Results: Of the 384 children, $85(22.1 \%)$ had E. vermicularis infestation. Age $(P=0.04)$, governorate $(P=0.01)$, residency $(P=0.03)$, number of household members $(P<0.001)$ and washing hands after toilet use $(P=0.01)$ were significantly associated with E. vermicularis infestation. In the logistic regression analysis, factors that increased the probability of infection were: living in villages (odds ratio (OR) 2.25; 95\% confidence interval (CI): 1.01-5.00), living in a household with $\geq$ nine family members (OR 3.63; 95\% CI: 1.42-9.26) and not washing hands after using the toilet (OR 2.4; 95\% CI: 1.30-4.40).

Conclusions: E. vermicularis is an important helminthic infestation among preschool children in Palestine. Efforts are needed to ensure the availability of treatment for infected children at primary care centres and to reinforce hygiene behaviour.

Keywords: Enterobius vermicularis, prevalence, risk factors; preschool children, Palestine.

Citation: Khayyat R; Belkebir S; Abuseir S; Barahmeh M; Alsadder L; Basha W. Prevalence of and risk factors for Enterobius vermicularis infestation in preschool children, West Bank, Palestine, 2015. East Mediterr Health J. 2021;27(11):1052-1060. https://doi.org/10.26719/emhj.21.022

Received: 23/12/20; accepted: 23/03/21

Copyright (C) World Health Organization (WHO) 2021. Open Access. Some rights reserved. This work is available under the CC BY-NC-SA 3.0 IGO license (https://creativecommons.org/licenses/by-nc-sa/3.o/igo)
\end{abstract}

\section{Introduction}

Parasitic infestations are prevalent throughout the world and are a public health burden, especially in developing countries where they cause more morbidity and mortality than other infectious diseases (1,2). Enterobius vermicularis (pinworms) is the least harmful of the gastrointestinal nematode helminths; it is considered more of a nuisance than a serious disease. It has the widest distribution of any parasitic helminths and humans are its only natural host $(3,4)$. Enterobius vermicularis also appears to be the oldest parasitic helminth to infect ancient populations (5). Studies in several countries around the world have shown a high prevalence of $E$. vermicularis in different age groups: for example, $30-80 \%$ in North America, $18 \%$ in China and $17 \%$ in Tanzania (6,7). Other studies indicate that a prevalence of more than $20 \%$ is common in many parts of the world (8).

Most infestations with gastrointestinal nematodes are asymptomatic. This may be why gastrointestinal nematode infestations including $E$. vermicularis infestation have been neglected in terms of public health recognition and research funding (1).
Enterobius vermicularis is most common in crowded residences among all ages, but is particularly common in children and affects between $4 \%$ and $28 \%$ of children worldwide $(9,10)$. This parasite is mostly found in children in kindergartens, institutions or in families with a large number of children. It spreads easily between all family members, with frequent reinfestation (11-13). Mother's employment and household income have also been shown to be risk factors for E. vermicularis infestation (14).

E. vermicularis can cause itching around the anus which can lead to difficulty sleeping and restlessness. This pruritus may also produce secondary lesions as mechanical dermatitis of the perianal or vulvar tissues (15). The presence of large numbers of adult worms in the bowel can cause abdominal pain, constipation, tenesmus and vaginitis $(4,15,16)$. Some evidence exists that $E$. vermicularis infestation may be a cause of secondary enuresis $(17,18)$. There have also been reported cases of appendicitis complicated by E. vermicularis infestation $(19,20)$. E. vermicularis was found responsible for $7 \%$ of acute cases of appendicitis (21).

Furthermore, this infestation has been reported to have the potential to cause inflammation that can 
affect children's growth, including salpingitis, ileocolitis, mesenteric abscess and urinary tract infection (22). It has been further reported to cause rectal malignancy (23) and create granuloma in the cecum, sigmoid colon, anal canal and extraintestinal tissues such as liver and ovary (24-26).

The main objective of this study was to determine the prevalence and risk factors of E. vermicularis infestation in preschool children in north West Bank, Palestine.

\section{Methods}

\section{Study design and setting}

We conducted a descriptive analytic cross-sectional study in north West Bank, Palestine. Samples were collected over a period of 7 months (May-November 2015) from six governorates in north West Bank, Palestine: Nablus, Jenin, Qalqilia, Salfeet, Tubas and Tulkarm. The population of these governorates was estimated to be more than1.1 million people, about 38\% of the Palestinian population in the West Bank (27).

We used Raosoft sample size calculator (Raosoft, Inc., USA) to calculate the sample size, with a $95 \%$ confidence interval (CI) and a 0.05 margin of error. As there were no previous studies in Palestine on the prevalence of E. vermicularis infestation, we assumed the expected population proportion to be 0.5 . The resulting sample size needed was 377 and the final sample size was 384 .

We obtained information from bureau of statistics on the number of children aged 3-5years in each governorate. We approached day-care centres and we included those that were willing to collaborate. From these centres, we selected a convenience sample of children aged 3-5 years proportionate to the number in each governorate.

A total of 86 day-care centres agreed to collaborate and 1300 sample kits, each containing a questionnaire and two scotch tapes, were distributed to children aged 3-5 years old who attended these centres over a period of 7 months from May to November 2015. We included children whose parents/guardians completed the questionnaire and provided the cellophane samples for testing.

\section{E. vermicularis detection}

Two cellophane tapes were given to each child's parent or guardian to use over two consecutive nights. Parents were given written and visual instructions on how to use the cellophane tapes and were asked to return them to the day-care centre. The tapes were sent to the microbiology laboratories of An-Najah National University where they were attached to glass slides and examined under light microscope. E. vermicularis infestation was considered positive if E. vermicularis eggs were found on at least one cellophane tape.

\section{Questionnaire}

A questionnaire (completed by parents/guardians) was used to collect data on demographic characteristics of the child and his/her parents, family socioeconomic status, personal hygiene, medical history of previous infesta- tion and clinical symptoms. The demographic section asked about the age and sex of the child, residency (city, village or refugee camp), number of children under the age of 9 years in the family, occupation of the mother and monthly income of the household. The personal hygiene section asked about certain behaviours, including washing hands after using the toilet and before meals, playing outdoors, biting nails, daily change of underwear, and the type and location of the toilet. Finally, the questionnaire asked about history of previous infestation with E. vermicularis, history of previous use of antihelminthic treatment for pinworms and the type of treatment used (herbal or pharmaceutical), and complaints of five clinical symptoms associated with E. vermicularis infestation: abdominal pain and discomfort, perianal itching, sleep disturbance, enuresis and change in appetite.

The questionnaire was based on an extensive literature review about risk factors of the development of E. vermicularis infestation $(6,7,12,14,28)$. We independently reviewed the items included for content and face validity to determine the extent to which the questions reflected the scope of the study objectives and covered all essential factors presumed to be related to E. vermicularis. We gave the final version to volunteer mothers to evaluate the face validity, language adequacy and time required to fill it; no further changes to its content were made.

\section{Statistical analysis}

We only included completed questionnaires for analysis. We used SPSS, version 21 for data processing and analysis. We report data as means and standard deviations (SD) and frequencies as appropriate. We used the chi-squared test for statistical analysis with $P<0.05$ set as the level of significance. We also used multivariable logistic regressions analysis to assess the association between the prevalence of E. vermicularis and potential risks factors.

\section{Ethical considerations}

The institutional review board committee at An-Najah National University approved the study protocol (archive number 20/March/2015).

The proposed procedure (use of cellophane tape for diagnosis) and the possible risks and benefits were explained to day-care centre principals and teachers. Communication with the parents/guardians of the participating children was mainly through teachers and principals of day-care centres. A written consent form was obtained from the parent/guardian of each participating child and they were informed if their child was found to be infected. Treatment for enterobiasis is available for free in primary health care centres and medical insurance for all children up to 5 years of age is provided by the Palestinian government without fees.

\section{Results}

The parents/guardians of 384 children complied with the instructions to use the tape over 2 consecutive nights, completed the questionnaire and returned both to the 
day-care centre (29.5\% response rate). Of the 384 children, $85(22.1 \%)$ were infected with E. vermicularis. Just over half the sample were boys (53.6\%). The prevalence of E. vermicularis infestation in boys was $24.3 \%$ compared with $19.7 \%$ in girls, but the difference was not statistically significant (Table 1). The age of participating children ranged from 3 to 5 years with a mean of 4.42 (SD 0.77) years.

With regard to governorate, $61.5 \%$ of the children were from either Nablus or Jenin. The prevalence of $E$. vermicularis infestation was the highest in Tubas (30.4\%), followed by Tulkarm (29.5\%), Jenin (28.8\%) and Qalqilia (26.3\%). Children from villages had the highest prevalence of infestation (33.9\%) followed by camps and cities (Table 1).

The number of household members ranged from 3 to 12 members, with a mean of 5.81 (SD 1.68). Children in families with $\geq 9$ family members had the highest prevalence of infestation (44.7\%). The number of children younger than 9-year-old in a household ranged from 1 to 6 children with a mean of 2.31 (SD 0.95). Families with $\geq 5$ children under 9 years had the highest prevalence of infestation (66.7\%), but this was not statically significant. Families with a household income between 1500 and 3500 new Israeli shekels (1 new Israeli shekel = US\$ 0.29)

Table 1 Distribution of children according to sociodemographic characteristics and Enterobius vermicularis infestation

\begin{tabular}{|c|c|c|c|c|c|}
\hline \multirow[t]{2}{*}{ Variable } & \multirow[t]{2}{*}{ No. $(\%)(n=384)$} & \multicolumn{2}{|c|}{$\%$ infected } & \multirow[t]{2}{*}{$\chi^{2 a}$} & \multirow[t]{2}{*}{ P-value ${ }^{\mathrm{b}}$} \\
\hline & & Yes & No & & \\
\hline \multicolumn{6}{|l|}{ Sex } \\
\hline Male & $206(53.6)$ & $50(24.3)$ & $156(75.7)$ & \multirow[t]{2}{*}{1.17} & \multirow[t]{2}{*}{0.27} \\
\hline Female & $178(46.4)$ & $35(19.7)$ & $143(80.3)$ & & \\
\hline \multicolumn{6}{|l|}{ Age (years) } \\
\hline 3 & $71(18.5)$ & $8(11.3)$ & $63(88.7)$ & \multirow[t]{3}{*}{6.04} & \multirow[t]{3}{*}{0.04} \\
\hline 4 & $106(27.6)$ & $27(25.5)$ & $79(74.5)$ & & \\
\hline 5 & $207(53.9)$ & $50(24.2)$ & $157(75.8)$ & & \\
\hline \multicolumn{6}{|l|}{ Governorate } \\
\hline Nablus & $132(34.4)$ & $17(12.9)$ & $115(87.1)$ & \multirow[t]{6}{*}{14.20} & \multirow[t]{6}{*}{0.01} \\
\hline Jenin & $104(27.1)$ & $30(28.8)$ & $74(71.2)$ & & \\
\hline Tubas & $23(6.0)$ & $7(30.4)$ & $16(69.6)$ & & \\
\hline Tulkarm & $61(15.9)$ & $18(29.5)$ & $43(70.5)$ & & \\
\hline Qalqilia & $38(9.9)$ & $10(26.3)$ & $28(73.7)$ & & \\
\hline Salfet & $26(6.8)$ & $3(11.5)$ & $23(88.5)$ & & \\
\hline \multicolumn{6}{|l|}{ Residence } \\
\hline City & $198(51.6)$ & $36(18.2)$ & $162(81.8)$ & \multirow[t]{3}{*}{6.56} & \multirow[t]{3}{*}{0.03} \\
\hline Village & $59(15.4)$ & $20(33.9)$ & $39(66.1)$ & & \\
\hline Refugee camp & $127(33.1)$ & $29(22.8)$ & $98(77.2)$ & & \\
\hline \multicolumn{6}{|l|}{ Household members, no. } \\
\hline$<5$ & $101(26.3)$ & $15(14.9)$ & $86(85.1)$ & \multirow[t]{3}{*}{14.40} & \multirow[t]{3}{*}{$<0.001$} \\
\hline $5-8$ & $245(63.8)$ & $53(21.6)$ & $192(78.4)$ & & \\
\hline$\geq 9$ & $38(9.9)$ & $17(44.7)$ & $21(55 \cdot 3)$ & & \\
\hline \multicolumn{6}{|l|}{ Children < 9 years, no. } \\
\hline$\leq 2$ & $248(64.6)$ & $54(21.8)$ & $194(78.2)$ & \multirow[t]{3}{*}{3.47} & \multirow[t]{3}{*}{0.17} \\
\hline $3-4$ & $133(34.6)$ & $29(21.8)$ & $104(78.2)$ & & \\
\hline$\geq 5$ & $3(0.8)$ & $2(66.7)$ & $1(33.3)$ & & \\
\hline \multicolumn{6}{|l|}{ Monthly income (new Israeli shekelc) } \\
\hline$<1500$ & $85(22.1)$ & $23(27.1)$ & $62(72.9)$ & \multirow[t]{3}{*}{$3.98^{\mathrm{d}}$} & \multirow[t]{3}{*}{0.13} \\
\hline $1500-3500$ & $250(65.1)$ & $56(22.4)$ & $194(77.6)$ & & \\
\hline$>3500$ & $49(12.8)$ & $6(12.7)$ & $43(87.8)$ & & \\
\hline \multicolumn{6}{|l|}{ Mother employment status } \\
\hline Works outside the home & $99(25.8)$ & $22(22.2)$ & $77(77.8)$ & \multirow[t]{2}{*}{0.00} & \multirow[t]{2}{*}{0.98} \\
\hline Does not work outside the home & $285(74.2)$ & $63(22.1)$ & $222(77.9)$ & & \\
\hline
\end{tabular}

Chi-squared test for independence.

${ }^{b}$ Significant at $P<5 \%$

C1 new Israeli shekel = US\$ 0.29 at the time of the study.

dFisher exact test. 
had the highest prevalence of infestation (65.9\%), but this was not statically significant (Table 1).

A statistically significant association was found between the prevalence of E. vermicularis infestation and age $(P=0.04)$, governorate $(P=0.01)$, residency $(P=0.03)$, and number of household members $(P<0.001)$.

Seated type toilet was used in $84 \%$ of the homes of the children. Washing hands after using the toilet was statistically significantly associated with $E$. vermicularis infestation $(P=0.01)$. No statistically significant associations were found between infestation with $E$. vermicularis infestation and other hygiene behaviours (Table 2).

Of the 384 participating children, $78(20.3 \%)$ had experienced previous infestation with $E$. vermicularis or their siblings had. Of these cases, 73 had received treatment, which was herbal therapy for four cases and pharmacological therapy for 69 cases. No statistically significant association was found between current infestation and being previously infested $(P=0.93)$.

No statistically significant association was found between having any of the symptoms and E. vermicularis infestation and having E. vermicularis infestation (Table 3).

We used multivariable logistic analysis to evaluate the association between the independent variables that were found significant or near significant $(P<0.1)$ in the bivariate analysis and E. vermicularis infestation, namely: age, governorate, residency, number of household members, washing hands after using the toilet, playing outdoors and nail biting (Table 4). The risk of infestation in preschool children living in Tubas, Qalqilia, Tulkarm and Jenin was higher than their peers living in Nablus (OR 3.95 (95\% CI: 1.29-12.07), OR 3.77 (95\% CI: 1.37-10.36), OR 3.30 (95\% CI: $1.45-7.54)$ and OR 3.469 (95\% CI: 1.59-7.50), respectively). Preschool children living in villages had 2.25 (95\% CI: 1.01-5.00) times higher odds of infestation with E. vermicularis than those living in cities. Preschool children living in families with $\geq 9$ household members had a more than 3 higher risk of infestation compared with those living in families of $\leq 4$ members (OR 3.63 (95\% CI: 1.42-9.26)). Children who washed their hands only sometimes after toilet use had 2.4 (95\% CI 1.34.4) times higher odds of infestation than children who always washed their hands (Table 4).

\section{Discussion}

The main objective of this study was to understand the prevalence and risk factors for E. vermicularis infestation in north West Bank, Palestine. The prevalence of E. vermicularis was found to be $22.1 \%$. The low response rate of $29.5 \%$ may be attributed to the discomfort parents/guardians felt when using cellophane tape test. Despite this low response rate, the applicability of our results was not affected because the minimum sample size was reached.

\begin{tabular}{|c|c|c|c|c|c|}
\hline \multirow[t]{2}{*}{ Variable } & \multirow[t]{2}{*}{ No. $(\%)(n=384)$} & \multicolumn{2}{|c|}{$\%$ infected } & \multirow[t]{2}{*}{$\chi^{2 \mathrm{a}}$} & \multirow[t]{2}{*}{ P-value ${ }^{b}$} \\
\hline & & Yes & No & & \\
\hline \multicolumn{6}{|l|}{ Toilet type } \\
\hline Squat type & $63(16.4)$ & $15(23.8)$ & $48(76.2)$ & \multirow[t]{2}{*}{0.12} & \multirow[t]{2}{*}{0.72} \\
\hline Seated type & $321(83.6)$ & $70(21.8)$ & $251(78.2)$ & & \\
\hline \multicolumn{6}{|c|}{ Washing hands after using toilet } \\
\hline Always & $268(69.8)$ & $50(18.7)$ & $218(81.3)$ & \multirow[t]{2}{*}{6.22} & \multirow[t]{2}{*}{0.01} \\
\hline Sometimes & $116(30.2)$ & $35(30.2)$ & $81(69.8)$ & & \\
\hline \multicolumn{6}{|c|}{ Washing hands before meals } \\
\hline Always & $155(40.4)$ & $41(26.5)$ & $114(73.5)$ & \multirow[t]{3}{*}{2.92} & \multirow[t]{3}{*}{0.23} \\
\hline Sometimes & $216(56.3)$ & $41(19.0)$ & $175(81)$ & & \\
\hline Never & $13(3.4)$ & $3(23.1)$ & $10(76.9)$ & & \\
\hline \multicolumn{6}{|l|}{ Playing outdoors } \\
\hline Yes & $329(85.7)$ & $76(23.1)$ & $253(76.9)$ & \multirow[t]{2}{*}{1.24} & \multirow[t]{2}{*}{0.26} \\
\hline No & $55(14.3)$ & $9(16.4)$ & $46(83.6)$ & & \\
\hline \multicolumn{6}{|l|}{ Nail biting } \\
\hline Yes & $151(39.3)$ & $41(27.2)$ & $110(72.8)$ & \multirow[t]{2}{*}{3.63} & \multirow[t]{2}{*}{0.057} \\
\hline No & $233(60.7)$ & $44(18.9)$ & $189(81.1)$ & & \\
\hline \multicolumn{6}{|c|}{ Frequency of changing underwear } \\
\hline Daily & $316(82.3)$ & $70(22.2)$ & $246(77.8)$ & \multirow{4}{*}{0.03} & \multirow{4}{*}{0.99} \\
\hline Twice a week & $35(9.1)$ & $8(22.9)$ & $27(77.1)$ & & \\
\hline Once a week & $9(2.3)$ & $2(22.2)$ & $7(77.8)$ & & \\
\hline Other & $24(6.3)$ & $5(20.8)$ & $19(79.2)$ & & \\
\hline
\end{tabular}




\begin{tabular}{|c|c|c|c|c|c|}
\hline \multirow[t]{2}{*}{ Symptom (yes) } & \multirow[t]{2}{*}{ No. $(\%)(n=384)$} & \multicolumn{2}{|c|}{$\%$ infected } & \multirow[t]{2}{*}{$\chi^{2 a}$} & \multirow[t]{2}{*}{ P-value } \\
\hline & & Yes & No & & \\
\hline \multicolumn{6}{|l|}{ Abdominal pain } \\
\hline Yes & $89(23.2)$ & $17(19.1)$ & $72(80.9)$ & \multirow[t]{2}{*}{0.61} & \multirow[t]{2}{*}{0.43} \\
\hline No & $295(76.8)$ & $68(23.1)$ & $227(76.9)$ & & \\
\hline \multicolumn{6}{|l|}{ Perianal itching } \\
\hline Yes & $77(20.1)$ & $20(26)$ & $57(74)$ & \multirow[t]{2}{*}{0.82} & \multirow[t]{2}{*}{0.36} \\
\hline No & $307(79.9)$ & $65(21.2)$ & $242(78.8)$ & & \\
\hline \multicolumn{6}{|l|}{ Sleep disturbance } \\
\hline Yes & $35(9.1)$ & $4(11.4)$ & $31(88.6)$ & \multirow[t]{2}{*}{2.56} & \multirow[t]{2}{*}{0.11} \\
\hline No & 349 (90.9) & $81(23.2)$ & $268(76.8)$ & & \\
\hline \multicolumn{6}{|l|}{ Enuresis } \\
\hline Yes & $42(10.9)$ & $9(21.4)$ & $33(78.6)$ & \multirow[t]{2}{*}{0.01} & \multirow[t]{2}{*}{0.90} \\
\hline No & $342(89.1)$ & $76(22.2)$ & $266(77.8)$ & & \\
\hline \multicolumn{6}{|l|}{ Change in appetite } \\
\hline Yes & $61(15.9)$ & $13(21.3)$ & $48(78.7)$ & \multirow[t]{2}{*}{0.02} & \multirow[t]{2}{*}{0.86} \\
\hline No & $323(84.1)$ & $72(22.3)$ & $251(77.7)$ & & \\
\hline \multicolumn{6}{|l|}{ Asymptomatic } \\
\hline Yes & $194(50.5)$ & $45(23.2)$ & $149(76.8)$ & \multirow[t]{2}{*}{0.25} & \multirow[t]{2}{*}{0.61} \\
\hline No & $190(49.5)$ & $40(21.1)$ & $150(78.9)$ & & \\
\hline
\end{tabular}

Chi-squared test for independence.

${ }^{b}$ Significant at $\mathrm{P}<5 \%$.

Infestation with E. vermicularis is clearly an important parasitic disease among preschool children in north West Bank. This finding is consistent with a study of the prevalence of parasites among children aged 6 to 11 years in Khan-Younis governorate, Gaza, Palestine, also using cellophane tape test to detect E. vermicularis. This study reported that $20.9 \%$ of the children examined were infected and infestation was more prevalent in boys than girls (27).

Our results are inconsistent with previous studies that had specifically underestimated the prevalence of $E$. vermicularis compared with other intestinal parasites in various geodemographic distributions in Palestine (29). A study to determine the prevalence of intestinal parasites in schoolchildren in three districts of north West Bank, Palestine using stool samples found the overall prevalence of parasitic infestation was $22.2 \%$, and the prevalence of infestation with E. vermicularis was 1.6\% (30). Another study in 1987 in Nablus city, north West Bank to detect the prevalence of intestinal parasites among city inhabitants, reported a prevalence of E. vermicularis infestation of $0.1 \%$ (31). This underestimation most probably resulted from the different diagnostic method used in these studies, since microscopic examination of adhesive perianal cellophane tape is the standard method for diagnosis of E. vermicularis rather than stool sample analysis.

The prevalence of E. vermicularis in our study is comparable to the prevalence found in studies conducted in other countries. For example, a Chinese study found that the prevalence of $E$. vermicularis infestation in children aged 2-12 years in nine autonomous regions in China, using adhesive cellophane swab, was $17.8 \%$ (6). Another cross-sectional study to assess Enterobiasis spp. and Strongyloidiasis spp. and associated coinfections and morbidity markers in infants, preschool and schoolaged children in coastal Tanzania found a prevalence of E. vermicularis infestation of $4.2 \%$ in infants, $16.7 \%$ in preschool children and $26.3 \%$ in school-aged children (7).

Although the prevalence of E. vermicularis infestation was higher in boys (24.3\%) than girls (19.7\%), the difference was not statistically significant. Other studies have shown higher prevalence of infestation in boys, which was assumed to be because boys had less hygienic behaviour than girls (32). Children aged 4 or 5 years had a higher prevalence of E. vermicularis infestation, $25.5 \%$ and $24.2 \%$, respectively. This can be probably attributed to the increased likelihood of children to self-manage and start taking care of their own hygiene at this age, which may result in an inadequate level of hygiene.

The highest prevalence of infestation was noted in Tubas governorate, followed by Jenin, Tulkarm and Qalqilia, which are mainly agricultural governorates. Although humans are the only host of E. vermicularis, a few studies have suggested that cockroaches are reservoirs for E. vermicularis, which might explain the higher prevalence in agricultural areas where the infrastructure is poorer than in the cities $(27,33)$. Residency in rural areas or in overcrowded household conditions was a risk factor for E. vermicularis infestation 


\begin{tabular}{|c|c|c|}
\hline Variable (reference category) & P-value & OR $(95 \% \mathrm{CI})$ \\
\hline Age & 0.10 & $1.34(0.93-1.93)$ \\
\hline \multicolumn{3}{|l|}{ Governorates (Nablus) } \\
\hline Tubas & 0.01 & $3.95(1.29-12.07)$ \\
\hline Qalqilia & 0.01 & $3.77(1.37-10.36)$ \\
\hline Tulkarm & $<0.001$ & $3.30(1.45-7.54)$ \\
\hline Salfet & 0.86 & $1.12(0.27-4.58)$ \\
\hline Jenin & $<0.001$ & $3.46(1.59-7.50)$ \\
\hline \multicolumn{3}{|l|}{ Residency (city) } \\
\hline Village & 0.04 & $2.25(1.01-5.00)$ \\
\hline Refugee camp & 0.47 & $1.33(0.60-2.93)$ \\
\hline \multicolumn{3}{|l|}{$\begin{array}{l}\text { Family size, no. of members } \\
\text { ( } \leq 4 \text { members) }\end{array}$} \\
\hline $5-8$ & 0.24 & $1.48(0.76-2.87)$ \\
\hline$\geq 9$ & $<0.001$ & $3.63(1.42-9.26)$ \\
\hline \multicolumn{3}{|l|}{$\begin{array}{l}\text { Washing hands after using the } \\
\text { toilet (always) }\end{array}$} \\
\hline Sometimes & $<0.001$ & $2.4(1.30-4.40)$ \\
\hline \multicolumn{3}{|l|}{ Playing outdoors (yes) } \\
\hline No & 0.56 & $0.89(0.60-1.31)$ \\
\hline \multicolumn{3}{|l|}{ Nail biting (no) } \\
\hline Yes & 0.56 & $1.7(0.98-2.96)$ \\
\hline
\end{tabular}

OR: odds ratio; CI: confidence interval.

Significant $p$ value $<5 \%$.

in our study. This is consistent with the known person-toperson transmission of E. vermicularis that occurs through handling of contaminated clothes or bed linens, and the likelihood of higher infestation rates in overcrowded places such day-care centres or schools (32).

Mother's occupation and monthly household income were not significantly associated with E. vermicularis infestation. These findings are consistent with other research that found socioeconomic factors, parent's education and household income to be irrelevant to $E$. vermicularis infestation (34).
Some hygiene behaviours in children can be assumed to increase the risk of E. vermicularis infestation. Not washing hands after using the toilet was associated with increased prevalence of E. vermicularis infestation, which is consistent with its transmission $(8,34)$. Other hygiene behaviours such as nail biting, frequency of changing underwear, washing hands before meals and playing outdoors were not associated with E. vermicularis infestation in our study. Furthermore, none of the known clinical symptoms of E.vermicularis infestation (abdominal pain, perianal itching, sleep disturbances, enuresis and change in appetite) were significantly associated with being infected, which is consistent with the fact that $E$. vermicularis infestation is often asymptomatic (3).

As limitations, we faced great challenges in recruiting participants and non-probabilistic sampling technique was used, therefore leading to potential selection bias that could undermine the real prevalence of pinworm among pre-schoolers. Besides, this study included only the north of Palestine, which means that we excluded some areas that may be poorer than the north of Palestine and also the Bedouins who live in difficult environmental and socio-economic situation, which may under-estimate the real prevalence of pinworms in Palestine. It was reported that environmental factors are important in the transmission of pinworm but in our study we did not take environmental samples as potential risk factors.

Our study shows that E. vermicularis infestation is an important parasitic infectious disease among Palestinian preschool children in north West Bank. The high prevalence of infestation was clearly associated with age of children, increased number of household members, hygiene behaviour and certain geodemographic distribution in north West Bank. We recommend that the Palestinian Ministry of Health highlight the presence of E. vermicularis infestation, ensure the availability of treatment for infected children and their families at primary care centres and reinforce hygiene behaviour, especially hand hygiene in preschool children.

\section{Acknowledgement}

Rasha Khayyat and Souad Belkebir contributed equally to this work.

Funding: None.

Competing interests: None declared.

\section{Facteurs de risque et prévalence de l'infestation par Enterobius vermicularis chez les enfants d'âge préscolaire, Cisjordanie (Palestine), 2015}

\section{Résumé}

Contexte : L'infestation par Enterobius vermicularis (oxyure) est une affection courante qui touche principalement les enfants.

Objectifs : La présente étude visait à évaluer les facteurs de risque et la prévalence de l'infestation par E. vermicularis chez les enfants d'âge préscolaire du nord de la Cisjordanie. 
Méthodes : Une étude transversale qui incluait les six principaux gouvernorats du nord de la Cisjordanie a été menée dans un échantillon de 384 enfants d'âge préscolaire fréquentant 86 garderies. La méthode de l'application d'un ruban adhésif autour de l'anus a été utilisée pour détecter l'infestation par E.vermicularis. Les parents/tuteurs des enfants participants ont rempli un questionnaire servant à recueillir diverses informations : caractéristiques démographiques ; comportement en matière d'hygiène; statut socioéconomique; antécédents d'infestation; et présence de symptômes. Les facteurs de risque d'infestation ont été évalués à l'aide d'une analyse de régression logistique.

Résultats: Sur les 384 enfants, 85 (22,1\%) présentaient une infestation par E.vermicularis. L'âge ( $p=0,04)$, le gouvernorat $(p=0,01)$, le lieu de résidence $(p=0,03)$, le nombre de membres du foyer $(p<0,001)$ et le non-lavage des mains après utilisation des toilettes $(p=0,01)$ étaient associés de manière significative à l'infestation par E. vermicularis. À l'analyse de régression logistique, les facteurs augmentant la probabilité d'infection étaient les suivants: le fait de vivre dans un village (odds ratio [OR] 2,25; intervalle de confiance (IC) à $95 \%: 1,01-5,00$ ), de vivre dans un foyer comptant au moins neuf membres d'une même famille (OR 3,63; IC à 95\%: 1,42-9,26) et de ne pas se laver les mains après un passage aux toilettes (OR 2,4 ; IC à $95 \%$ : 1,30-4,40).

Conclusions: E.vermicularis cause une helminthiase importante chez les enfants d'âge préscolaire en Palestine. Des efforts doivent être déployés afin de garantir la disponibilité du traitement dans les centres de soins de santé primaires pour les enfants infestés et de renforcer les comportements en matière d'hygiène.

$$
\begin{aligned}
& \text { معدل انتشار الإصابة بالشُّريَّة الدوديّة وعوامل الخطر المسببة لما في صفوف الأطفال دون سن المدرسة، الضفة } \\
& \text { الغربية، فلسطين } \\
& \text { رشا خياط، سعاد بلكبير، سامح أبوصير، ماجد براهمة، لجين الصدر، وليد باشا } \\
& \text { الخلاصة } \\
& \text { الخلفية: الإصابة بالسُّرمية الدودية (الدودة الدبوسية) تُعلُّ حالة شائعة تصيب الأطفال في المقام الأول. }
\end{aligned}
$$

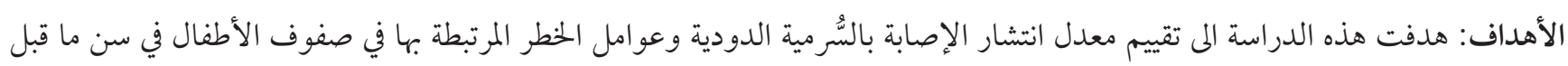
المدرسة في شمال الضفة الغربية.

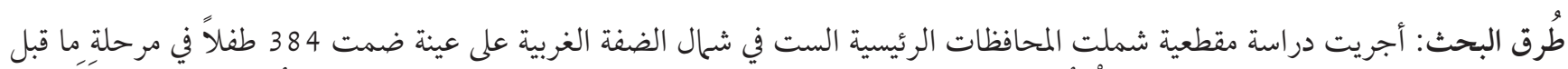

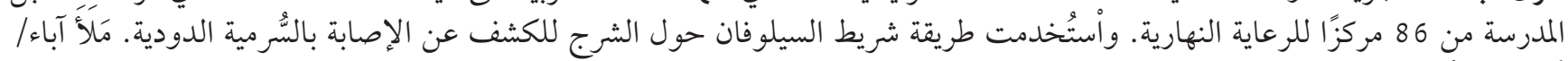

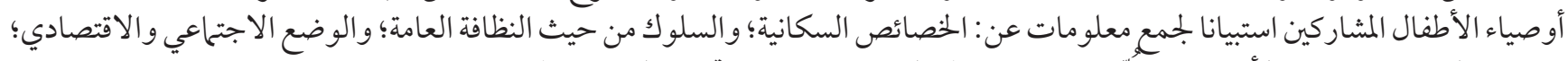

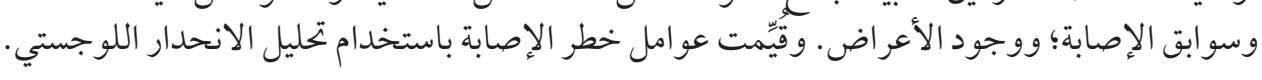

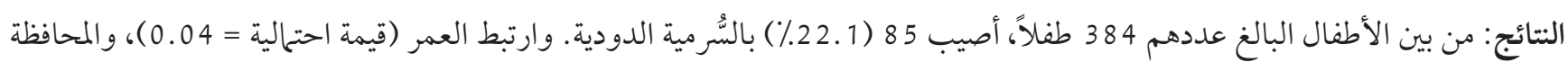

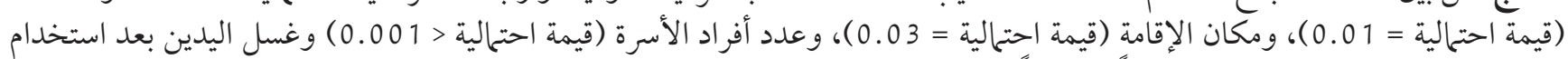

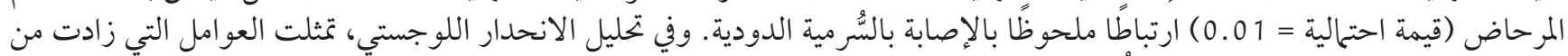

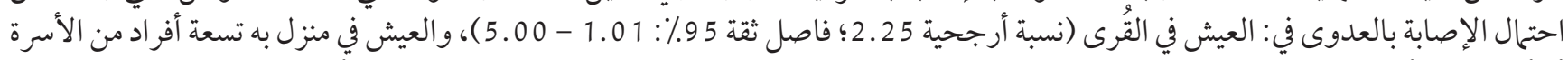

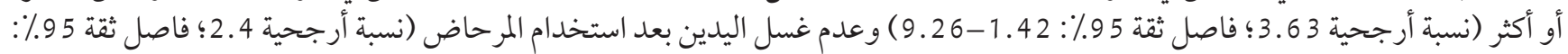

. $(4.40-1.30$

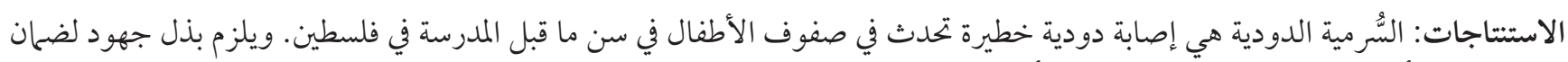

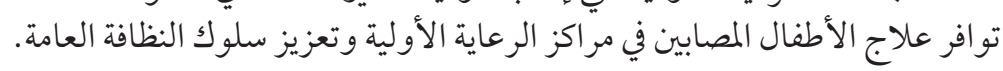

\section{References}

1. Stepek G, Buttle DJ, Duce IR, Behnke JM. Human gastrointestinal nematode infections: are new control methods required? Int J Exp Pathol. 2006;87:325-41. https://doi.org/10.1111/j.1365-2613.2006.00495.x

2. Medkour HH, Amona I, Laidoudi Y, Davoust B, Bitam I, Levasseur A, et al. Parasitic infections in African humans and non-human primates. Pathogens. 2020;9(7):561. https://doi.org/10.3390/pathogens9070561

3. Parasites [Internet]. Atlanta: Centers for Disease Control and Prevention; (https://www.cdc.gov/parasites/index.html, accessed 17 June 2021).

4. Chitnis A, Azimi DY, Sabri S, Dhebri A. Enterobius vermicularis: a parasitic cause of appendicular colic. Cureus. 2020;12(6):e8524. https://doi.org/10.7759/cureus.8524 
5. Paknazhad N, Mowlavi G, Dupouy Camet J, Jelodar ME, Mobedi I, Makki M, et al. Paleoparasitological evidence of pinworm (Enterobius vermicularis) infection in a female adolescent residing in ancient Tehran (Iran) 7000 years ago. Parasit Vectors. 2016;22:9:33. https://doi.org/10.1186/s13071-016-1322-y

6. Chen YD, Wang JJ, Zhu HH, Zhu TJ, Zang W, Qian M-B, et al. [Enterobius vermicularis infection status among children in 9 provinces/autonomous regions/municipalities of China.] [Chinese J Parasitol Parasit Dis]. 2013;31(4):251-55. [in Chinese]

7. Salim N, Schindler T, Abdul U, Rothen J, Genton B, Lweno O, et al. Enterobiasis and strongyloidiasis and associated co-infections and morbidity markers in infants, preschool- and school-aged children from rural coastal Tanzania: a cross-sectional study. BMC Infect Dis. 2014;14:644. https://doi.org/10.1186/s12879-014-0644-7

8. Chen KY, Yen CM, Hwang KP, Wang LC. Enterobius vermicularis infection and its risk factors among pre-school children in Taipei, Taiwan. J Microbiol Immunol Infect. 2018;51(4):559-64. https://doi.org/10.1016/j.jmii.2016.12.013

9. Altun E, Avci V, Azatcam M. Parasitic infestation in appendicitis. A retrospective analysis of 660 patients and brief literature review. Saudi Med J. 2017;38(3):314-8. https://doi.org/10.15537/smj.2017.3.18061

10. Zouari M, Louati H, Abid I, Trabelsi F, Ben Dhaou M, Jallouli M, et al. Enterobius vermicularis: a cause of abdominal pain mimicking acute appendicitis in children. A retrospective cohort study. Arch Iran Med. 2018;21(2):67-72.

11. Gonzalez S, De la Cabada FJ. Parasitic infections of the colon and rectum. Baillieres Clin Gastroenterol. 1987;1(2):447-67. https:// doi.org/10.1016/0950-3528(87)90013-3

12. Cook GC. Enterobius vermicularis infections. Gut. 1994;35(9):1159-62. https://doi.org/10.1136/gut.35.9.1159

13. Kucik CJ, Martin GL, Sortor BV. Common intestinal parasites. Am Fam Physician. 2004;69(5):1161-9.

14. Muge OA, Baykan Z, Artan C. Enterobiasis among preschool children: a study from Kayseri, Turkey. Jpn J Infect Dis. 2008;61(6):482-3.

15. Kacker PP. Vulvo-vaginitis in an adult with thread-worms in the vagina. Br J Vener Dis. 1973;49(3):314-5. https://doi.org/10.1136/ sti.49.3.314

16. Mentessidou A, Theocharides C, Patoulias I, Panteli C. Enterobius vermicularis-associated pelvic inflammatory disease in a child. J Pediat Adolescent Gynecol. 2016;29(2):e25-e7. https://doi.org/10.1016/j.jpag.2015.10.010

17. Mayers CP, Purvis RJ. Manifestations of pinworms. Can Med Assoc J. 1970;103(12):489-93.

18. Al-Qadhi BN, Al-Warid HSJ, Al-Qadhi MN. Enterobiasis and its relationship with enuresis among one of orphanage care children in Baghdad-Iraq. Iraqi J Sci. 2011;52(3):394-9.

19. Maki AC, Combs B, McClure B, Slack P, Matheson P, Wiesenauer C. Enterobius vermicularis: a cause of acute appendicitis in children. Am Surg. 2012;78(12):E523-4.

20. Martinez-Criado Y, Millan-Lopez A, Galan N, De-Agustin-Asensio JC. Acute appendicitis by Enterobius vermicularis: an unusual etiology in children. Rev Esp Enferm Dig. 2012;104(7):393-4. https://doi.org/10.4321/s1130-01082012000700016

21. Fleming CA, Kearney DE, Moriarty P, Redmond HP, Andrews EJ. An evaluation of the relationship between Enterobius vermicularis infestation and acute appendicitis in a paediatric population: a retrospective cohort study. Int J Surg. 2015;18:154-8. https:// doi.org/10.1016/j.ijsu.2015.02.012

22. Sodergren MH, Jethwa P, Wilkinson S, Kerwat R. Presenting features of Enterobius vermicularis in the vermiform appendix. Scand J Gastroenterol. 2009;44:457-61. https://doi.org/10.1080/00365520802624227

23. Akıncı A, Kepil N, Erzin YZ, Zengin AK. Enterobius vermicularis infestation mimicking rectal malignancy. Turkiye Parazitol Derg. 2020;44(1):58-60. https://doi.org/10.4274/tpd.galenos.2019.6617

24. Bharathi K, Anuradha S, Chandrasekar VA, Thirunarayanan R. Enterobius vermicularis worm granuloma mimicking like a pseudo tumor in the anal canal: an unusual clinical presentation. Trop Parasitol. 2012;2(2):124-6. https://doi.org/10.4103/22295070.105178

25. Arkoulis N, Zerbinis H, Simatos G, Nisiotis A. Enterobius vermicularis (pinworm) infection of the liver mimicking malignancy: presentation of a new case and review of current literature. Int J Surg Case Rep. 2012;3(1):6-9. https://doi.org/10.1016/j. ijscr.2011.10.003

26. Elsaid N, Mahmood H, Tekkis P, Tan E. Enterobiasis-related inflammatory caecal polyp masquerading as a malignancy. BMJ Case Rep. 2014;2014:bcr2013201599. https://doi.org/10.1136/bcr-2013-201599.

27. Estimated population in Palestine mid-year by governorate, 1997-2021. Ramallah: Palestinian Central Bureau of Statistics; 2021 (http://www.pcbs.gov.ps/Portals/_Rainbow/ Documents/\%D8\%A7\%D9\%84\%D9\%85\%D8\%AD\%D8\%A7\%D9\%81\%D8\%B8\%D8\%A7\%D8\%AA\%20\%D8\%A7\%D9\%86\%D8\%AC\%D9\%84 \%D9\%8A\%D8\%B2\%D9\%8A\%2097-2017.html, accessed 17 June 2021).

28. Astal Z. Epidemiological survey of the prevalence of parasites among children in Khan Younis governorate, Palestine. Parasitol Res. 2004;94(6):449-51. https://doi.org/10.1007/s00436-004-1234-1

29. Mezeid N, Shaldoum F, Al-Hindi AI, Mohamed FSA, Darwish ZEA. Prevalence of intestinal parasites among the population of the Gaza Strip, Palestine. Ann Parasitol. 2014;60(4):281-9.

30. Hussein AS. Prevalence of intestinal parasites among children in northern districts of West Bank, Palestine. Trop Med Int Health. 2011;16(2):240-4. https://doi.org/10.1111/j.1365-3156.2010.02674.x 
31. Ali-Shtayeh MS, Hamdan AH, Shaheen SF, Abu-Zeid I, Faidy YR. Prevalence and seasonal fluctuations of intestinal parasitic infections in the Nablus area, West Bank of Jordan. Ann Trop Med Parasitol. 1989;83(1):67-72. https://doi.org/10.1080/00034983.1 989.11812312

32. Gunawardena NK, Chandrasena TN, de Silva NR. Prevalence of enterobiasis among primary school children in Ragama, Sri Lanka. Ceylon Med J. 2013;58(3):106-10. https://doi.org/10.4038/cmj.v58i3.5039

33. Chan OT, Lee EK, Hardman JM, Navin JJ. The cockroach as a host for Trichinella and Enterobius vermicularis: implications for public health. Hawaii Med J. 2004;63(3):74-7.

34. Li HM, Zhou CH, Li ZS, Deng ZH, Ruan CW, Zhang QM, et al. Risk factors for Enterobius vermicularis infection in children in Gaozhou, Guangdong, China. Infect Dis Poverty. 2015;4:28. https://doi.org/10.1186/s40249-015-0058-9 